\title{
Tracking a TGF- $\beta$ activator in vivo: sensitive PET imaging of av $\beta 8$-integrin with the Ga-68-labeled cyclic RGD octapeptide trimer Ga-68-Triveoctin
}

\author{
Neil Gerard Quigley ${ }^{1}$, Katja Steiger ${ }^{1}$, Frauke Richter ${ }^{1}$, Wilko Weichert ${ }^{1}$, Sebastian Hoberück ${ }^{2}$, Jörg Kotzerke ${ }^{2}$
} and Johannes Notni ${ }^{1 *}$ (1)

\begin{abstract}
Purpose: As a major activator of transforming growth factor $\beta$ (TGF- $\beta$ ), the RGD receptor av $\beta 8$-integrin is involved in pathogenic processes related to TGF- $\beta$ dysregulation, such as tumor growth, invasion, and radiochemoresistance, metastasis and tumor cell stemness, as well as epithelial-mesenchymal transition. The novel positron emission tomography (PET) radiopharmaceutical Ga-68-Triveoctin for in vivo mapping of av $\beta 8$-integrin expression might enhance the prognosis of certain tumor entities, as well as support and augment TGF- $\beta$-targeted therapeutic approaches.

Methods: Monomeric and trimeric conjugates of cyclo(GLRGDLp(NMe)K(pent-4-ynoic amide)) were synthesized by click chemistry (CUAAC), labeled with Ga-68, and evaluated in MeWo (human melanoma) xenografted SCID mice by means of PET and ex-vivo biodistribution. av $\beta 8$-integrin expression in murine tissues was determined by $\beta 8-\mathrm{IHC}$. A human subject received a single injection of $173 \mathrm{MBq}$ of Ga-68-Triveoctin and underwent 3 subsequent PET/CT scans at 25,45 , and 90 min p.i..

Results: The trimer Ga-68-Triveoctin exhibits a 6.7-fold higher avß8-integrin affinity than the monomer (IC 50 of 5.7 vs. $38 \mathrm{nM}$, respectively). Accordingly, biodistribution showed a higher tumor uptake (1.9 vs. $1.0 \% \mathrm{IA} / \mathrm{g}$, respectively) but a similar baseline upon blockade $(0.25 \% \mathrm{lA} / \mathrm{g}$ for both). $\mathrm{IHC}$ showed an intermediate $\beta 8$-expression in the tumor while most organs and tissues were found $\beta 8$-negative. Low non-target tissue uptakes $(<0.4 \% \mathrm{IA} / \mathrm{g})$ confirmed a low degree of unspecific binding. Due to its hydrophilicity $(\log D=-3.1)$, Ga-68-Triveoctin is excreted renally and shows favorable tumor/tissue ratios in mice (t/blood: 6.7; t/liver: 6.8; t/muscle: 29). A high kidney uptake in mice (kidney-to-blood and -to-muscle ratios of 126 and 505, respectively) is not reflected by human PET (corresponding values are 15 and 30, respectively), which furthermore showed notable uptakes in coeliac and choroid plexus (SUVmean 6.1 and 9.7, respectively, 90 min p.i.).
\end{abstract}

Conclusion: Ga-68-Triveoctin enables sensitive in-vivo imaging avß38-integrin expression in murine tumor xenografts. PET in a human subject confirmed a favorable biodistribution, underscoring the potential of Ga-68-Triveoctin for mapping of avß8-integrin expression in a clinical setting.

Keywords: Integrins, Beta8, Transforming growth factor beta, Positron emission tomography, Gallium-68, Preclinical imaging

\footnotetext{
*Correspondence: johannes.notni@tum.de

${ }^{1}$ Institut für Pathologie Und Pathologische Anatomie, Technische

Universität München, Trogerstraße 18, 81675 Munich, Germany

Full list of author information is available at the end of the article
} 


\section{Background}

$\beta 8$-Integrin was first described in 1991 [1] as one of five $\beta$-integrins $(\beta 1,-3,-5,-6$, and -8$)$ pairing with the $\alpha v$ monomer, which is the only $\alpha$ integrin it dimerizes with. Although $\alpha v \beta 8$ is comparable to other $\alpha v$ integrins (particularly $\alpha v \beta 3$ ) in that it recognizes the extracellular matrix $(\mathrm{ECM})$ protein vitronectin $(\mathrm{Vn})$ by the arginineglycine-aspartate (RGD) sequence contained therein, its uniqueness is manifested by the fact that unlike $\alpha v \beta 3$, $\alpha v \beta 5$, or $\alpha v \beta 1$, transmembrane $\alpha v \beta 8$ does not exert adhesive forces, i.e., does not promote cell binding to $\mathrm{Vn}$ [2]. Hence, unlike other integrins which transmit physical forces and thereby enable the adhesion of cells to ECM proteins, $\alpha v \beta 8$ appears to be involved mainly into signaling.

Mounting experimental evidence suggested that explaining the biological role and significance of $\alpha \mathrm{v} \beta 8$ integrin requires, in essence, a closer view on a family of mammalian cytokines called transforming growth factor beta (TGF- $\beta 1$ and -3 , herein referred to as TGF- $\beta$ ) [3]. TGF- $\beta$ is produced by almost any cell type and secreted into the extracellular space, albeit not as a free protein ligand capable of binding to its respective receptor, but as a "protected", i.e., inactive, aggregate with another inhibitory protein referred to as latency-associated peptide (LAP). This aggregate, called small latency complex (SLC), is often covalently linked to the ECM by another protein called latent TFG- $\beta$ binding protein (LTBP), forming the so-called large latent complex (LLC). An essential functionality of $\alpha v$-integrins (above all, $\alpha v \beta 8$, and $\alpha v \beta 6$ ) is their ability to release TGF- $\beta$ from its complex with LAP by binding to a RGD sequence contained therein $[4,5]$. Again, $\alpha v \beta 8$-integrin displays a unique mode of action. While a pulling force exerted by $\alpha \mathrm{v} \beta 6$ integrin distorts the structure of LAP and exposes TGF- $\beta$ to its receptor $[6,7], \alpha v \beta 8$ achieves a similar result by dragging the SLC into close proximity of matrix metalloprotease 14 (MMP14, synonym: MT1-MMP), which cleaves LAP and thereby generates free TGF- $\beta$ [8]. Taken together, expression of $\alpha \mathrm{v} \beta 8$-integrin first and foremost enables cells to liberate TGF- $\beta$ from its latent complexes in the extracellular space, and $\alpha v \beta 8$ expression is therefore closely connected to TGF- $\beta$-related signaling and its role in pathogenesis, particularly of fibrosis and cancer [9].

Generally, TGF- $\beta$ acts as a growth suppressor onto normal cells and may function as a tumor suppressor [10]. For instance, compared to normal airway epithelium, a low $\alpha v \beta 8$-integrin expression was found in epithelial lung cancers, which apparently supports its progression because low $\alpha v \beta 8$ results in reduced TGF- $\beta$ levels and consequently derogated tissue homeostasis [11]. However, tumor cells may also escape the growth-inhibiting effect of TGF- $\beta$ by means of altered downstream pathways, for instance, a Ser-15 mutation on p53 [12] or a loss of Smad4 [13]. Hence, any means of increasing the concentration of activated TGF- $\beta$ in their surrounding, for instance by $\alpha v \beta 8$-integrin upregulation, is assumed to give such cells a growth advantage over normal cells, turning TGF- $\beta$ into a tumor growth promoter [9]. For TGF- $\beta$-resistant tumors, a concomitant $\alpha \mathrm{v} \beta 8$ upregulation must therefore be expected to promote invasion and metastasis, particularly because TGF- $\beta$ also stimulates angiogenesis, epithelial-mesenchymal transition (EMT), cell motility, tumor cell stemness, and colonization of the metastatic niche [14]. Such pathogenic mechanisms have, for example, been detailed for glioblastoma (GBM) [15] and prostate cancer [16] cell lines, and for astrocytes which may control the angiogenic activity of adjacent endothelial cells by $\alpha v \beta 8$-integrin expression-mediated regulation of local TGF- $\beta$ levels [17]. In addition, other $\alpha v \beta 8$-dependent signalling axes, e.g., involving RhoGDI1, may also be relevant for pathogenesis [18].

In view of its multifaceted role in human pathology and oncogenesis, we anticipate a substantial scientific and clinical value for in-vivo mapping of physiological and pathological $\alpha v \beta 8$-integrin expression patterns. For this purpose, we developed ${ }^{68} \mathrm{Ga}$-Triveoctin, a ${ }^{68} \mathrm{Ga}$-labeled trimer of the $\alpha \mathrm{v} \beta 8$ selective octapeptide $c(G L R G D L p(N M e) K)$ [19] suitable for imaging of $\alpha v \beta 8$-integrin expression by means of positron emission tomography (PET).

\section{Methods \\ General}

Synthesis and characterization of Triveoctin is described in the Additional file 1. The integrin affinities were determined by a solid-phase binding assay, applying a previously described protocol [20]. $\beta 8$ immunohistochemistry stainings were done as described [18]. All animal studies have been performed in accordance with general animal welfare regulations in Germany and the institutional guidelines for the care and use of animals. ${ }^{68} \mathrm{Ga}$ radiolabeling [21], cultivation of MeWo cells and generation of respective subcutaneous xenografts [18], determination of $n$-octanol/phosphate-buffered saline (PBS) distribution coefficients $(\log D)$ and ex-vivo biodistribution studies [22], and $\mu$ PET imaging [23] were done as described previously in detail (a brief summary is provided in the following).

\section{Radiochemistry and preclinical studies}

For fully automated ${ }^{68} \mathrm{Ga}$ labeling, non-processed eluate of a ${ }^{68} \mathrm{Ge} /{ }^{68} \mathrm{Ga}$-generator with a $\mathrm{SnO}_{2}$ matrix (by IThemba LABS, SA; $1.25 \mathrm{~mL}, 1 \mathrm{M} \mathrm{HCl}$, eluted ${ }^{68} \mathrm{Ga}$ activity approx. $700 \mathrm{MBq}$ ) was adjusted to $\mathrm{pH} 2$ by adding 
HEPES buffer ( $400 \mu \mathrm{L}$ of a $2.7 \mathrm{M}$ solution), used to label $2 \mathrm{nmol}$ of Triveoctin or TRAP-AvB8 for $3 \mathrm{~min}$ at $95{ }^{\circ} \mathrm{C}$, which was purified by solid-phase extraction using a Sep$\mathrm{Pak}^{\circledR} \mathrm{C} 8$ light cartridge (Waters). Radiochemical yields were $95.8 \pm 1.3 \%(n=10)$, referring to the final product after purification. Quality control was performed by radio-TLC with citrate buffer, confirming $>99 \%$ purity (referring to absence of non-complexed ${ }^{68} \mathrm{Ga}$, see Figure S3). Distribution coefficients $(\log D)$ were determined by shake-flask method using n-octanol and PBS.

MeWo cells $\left(\mathrm{ATCC}^{\circledR}, \mathrm{HTB}^{-65^{\mathrm{TM}}}\right)$ were grown at $37^{\circ} \mathrm{C}$ under $5 \% \mathrm{CO}_{2}$ atmosphere in DMEM/HAM (Biochrom, Berlin, Germany) with $10 \%$ fetal calf serum (Thermo Fisher). Approx. $10^{7}$ cells were subcutaneously injected with Matrigel ${ }^{\circledR}$ (Corning, \#354262) into the right shoulder of 6-8-week-old female CB17 severe combined immunodeficiency (SCID) mice, which were used about 2-3 weeks later for PET and biodistribution.

For ocular autoradiography and histology, a mouse was sacrificed $50 \mathrm{~min}$ after injection of $12 \mathrm{MBq}{ }^{68} \mathrm{Ga}$ Triveoctin. The eyes were excised, rinsed with PBS and embedded in Sakura Tissue-Tek ${ }^{\circledR}$. After equilibrium had been reached at $-20{ }^{\circ} \mathrm{C}$, lateral $50-\mu \mathrm{m}$ cross sections were cut on a cryostat microtome (Leica CM1950) and thaw-mounted on SuperFrost Plus microscope slides. The slides were air-dried on a heating plate and exposed to an imaging plate from 45 min after sacrifice onwards overnight. The imaging plate was read out by a CR-35 Bio Scanner (Raytest). Gaussian smoothing was applied to the final images. The same sections were subsequently HE-stained in a standard automated process.

\section{PET imaging in human}

Using a fully automated synthesis module, the eluate of a ${ }^{68} \mathrm{Ge} /{ }^{68} \mathrm{Ga}$ generator (by Eckert \& Ziegler, Berlin, Germany; $0.1 \mathrm{M} \mathrm{HCl}$, approx. $500 \mathrm{MBq}{ }^{68} \mathrm{Ga}$ ) was directly eluted into the reaction vial containing Triveoctin $(35 \mu \mathrm{g})$ and adjusted to $\mathrm{pH} 4.5$ with sodium acetate. After heating for $4 \mathrm{~min}$ at $95{ }^{\circ} \mathrm{C}$, the mixture was passed over a solid-phase extraction cartridge (Waters Sep-Pak ${ }^{\circledR}$ light tC-18), which was purged with water $(10 \mathrm{~mL})$. Thereafter, ${ }^{68} \mathrm{Ga}$-Triveoctin was eluted with ethanol/water mixture (1:1 by volume, $1 \mathrm{~mL}$ ), followed by isotonic saline $(9 \mathrm{~mL})$. The formulation containing approx. 5\% ethanol was passed through a $0.22-\mu \mathrm{m}$ filter into a sterile injection vial and dispensed for injection. Quality control was done by radio-HPLC using a Shimadzu system equipped with a column Chromolith ${ }^{\circledR}$ Performance RP18e (Phenomenex, Aschaffenburg, Germany), gradient 0-100\% acetonitrile in water within $15 \mathrm{~min}$, flow rate $1.4 \mathrm{~mL} / \mathrm{min}$, $t_{\mathrm{R}}=8.53 \mathrm{~min}$, and met the in-house specifications for ${ }^{68} \mathrm{Ga}$-labeled compounds (>95\%).
Application of ${ }^{68} \mathrm{Ga}$-Triveoctin was done according to $\$ 13 / 2 \mathrm{~b}$ of the German Drug Act (Arzneimittelgesetz). A human subject received a single intravenous injection of ${ }^{68} \mathrm{Ga}$-Triveoctin (173 MBq, approx. $25 \mu \mathrm{g}$; for radiolabeling and QC, see Additional file 1). There were no adverse or clinically detectable pharmacologic effects. No significant changes in vital signs or the results of laboratory studies or electrocardiograms were observed. 25 min p.i., the patient underwent a list-mode PET/CT imaging protocol on a Biograph Vision 600 (Siemens Healthineers, Knoxville, USA). A standard low-dose CT was acquired from the whole body (X-ray tube current $10 \mathrm{~mA}$, tube voltage $100 \mathrm{kV}$, spiral pitch factor $1.5,3.0 \mathrm{~mm}$ slice thickness) and used for absolute scatter correction of the subsequent PET scan. The emission PET scan was acquired over 19 min using continuous bed motion with a speed of $2.2 \mathrm{~mm} \mathrm{~s}^{-1}$ for the legs and $1.4 \mathrm{~mm} \mathrm{~s}^{-1}$ for the remaining body. The PET scan was repeated $45 \mathrm{~min}$ p.i. without another CT scan. Another PET/CT imaging sequence was acquired $90 \mathrm{~min}$ p.i. as the subject had to leave the scanner for voiding. All scans were obtained during normal breathing. PET images were reconstructed using the TRueX algorithm with 4 iterations, 5 subsets, time-offlight (TOF) application and without filtering. Resulting PET images had an image matrix size of $440 \times 440$ with a

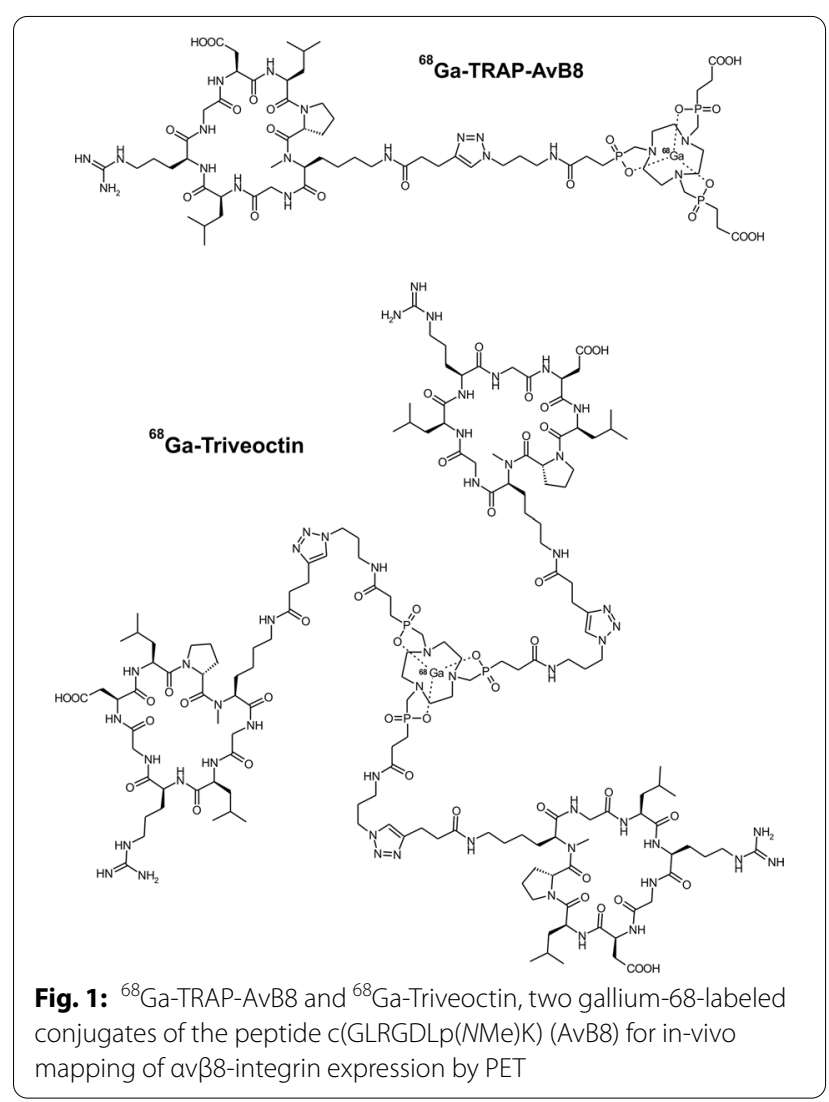


voxel size of $1.65 \times 1.65 \times 3.0 \mathrm{~mm}$. The dosimetry values were calculated using OLINDA V1.1 [24] on the basis of the human PET data.

\section{Results}

\section{Synthesis and affinity data}

Design of the ${ }^{68} \mathrm{Ga}$-peptides was done adopting a synthetically robust scheme [25] which has been successfully employed previously for elaboration of mono- and multimeric $\alpha v \beta 6$-integin ligands [26] or PSMA inhibitors [27]. Azide-decorated derivatives of a TRAP chelator [28] (more precisely, 1,4,7-triazacyclononane-1,4,7-tris [methylene(2-carboxyethyl)]phosphinic acid) [29] were coupled to the respective alkyne-functionalized peptidic building block AvB8-pentynoic amide by means of click chemistry (CuAAC) [30]. Subsequent ${ }^{68} \mathrm{Ga}$ labeling afforded the novel trimer ${ }^{68} \mathrm{Ga}$-Triveoctin (Fig. 1) and the previously described monomer

Table 1 av $\beta 8$-Integrin affinities (expressed as $50 \%$ inhibition concentrations, $\left.I C_{50}\right)$ and n-octanol-PBS distribution coefficients $\left(\log D_{7.4}\right)$. Affinities were determined using the non-radioactive ${ }^{69 / 71} \mathrm{Ga}^{\text {III }}$ complexes, where applicable

\begin{tabular}{lcl}
\hline Compound & $\begin{array}{l}\mathbf{I C}_{\mathbf{5 0}} \text { (95\% confidence } \\
\text { interval) [nM] }\end{array}$ & $\log \boldsymbol{D}_{\mathbf{7 . 4}}$ \\
\hline${ }^{68}$ Ga-Triveoctin (trimer) & $5.7(3.6-9.0)$ & $-3.1 \pm 0.1$ \\
${ }^{68}$ Ga-TRAP-AvB8 (monomer) & $38(25-58)$ & $-3.9 \pm 0.1$ \\
AvB8-pentynoic amide & $17(12-24)$ & $\mathrm{n} / \mathrm{a}$ \\
\hline
\end{tabular}

${ }^{68} \mathrm{Ga}$-TRAP-AvB8 [18] (for reaction schemes and details on syntheses, see Additional file 1).

In comparison with the linker-decorated peptide, the monomeric conjugate showed only approx. half of the biological activity $\left(\mathrm{IC}_{50}\right.$ of 38 vs. $17 \mathrm{nM}$, respectively). Trimerization, however, resulted in a threefold and 6.7fold higher target affinity for Ga-Triveoctin as compared to the neat peptide and the chelator monomer, respectively (Table 1).

\section{Preclinical in-vivo characterization}

Consistent with its higher $\alpha v \beta 8$-integrin affinity, dynamic PET data illustrate that the trimer ${ }^{68} \mathrm{Ga}$-Triveoctin shows a substantial better tumor retention than the monomer ${ }^{68}$ Ga-TRAP-AvB8 (Fig. 2). However, the trimer also exhibits a slower clearance from muscle and blood, which might be attributed to its larger molecular size and to its slightly lower hydrophilicity (Table 1).

This result is corroborated by biodistribution data (Fig. 3). Although the background uptake in all tissues is low for both tracers, a noticeably higher level is observed for ${ }^{68} \mathrm{Ga}$-Triveoctin. However, in terms of contrast, this is compensated for by an almost two times higher tumor uptake, ultimately resulting in somewhat larger tumor-to-organ ratios of the trimer (Fig. 3).

Interestingly, there are striking exceptions, namely the lung and the eye, showing blockable uptake of ${ }^{68} \mathrm{Ga}$-Triveoctin but not of ${ }^{68} \mathrm{Ga}-\mathrm{TRAP}-\mathrm{AvB} 8$. Autoradiography of a lateral eyeball cryoslice indicated that the activity


Fig. 2 Kinetics for ${ }^{68} \mathrm{Ga}$-Triveoctin (black lines; $11 \pm 1 \mathrm{MBq}, 64 \pm 13 \mathrm{pmol}, 182 \pm 30 \mathrm{MBq} / \mathrm{nmol}$ ) and ${ }^{68} \mathrm{Ga}-\mathrm{TRAP}-\mathrm{AvB} 8$ (blue; $11 \pm 1 \mathrm{MBq}$, $151 \pm 107 \mathrm{pmol}, 93 \pm 50 \mathrm{MBq} / \mathrm{nmol})$, derived from dynamic PET data in MeWo-xenografted SCID mice $(n=3)$ 

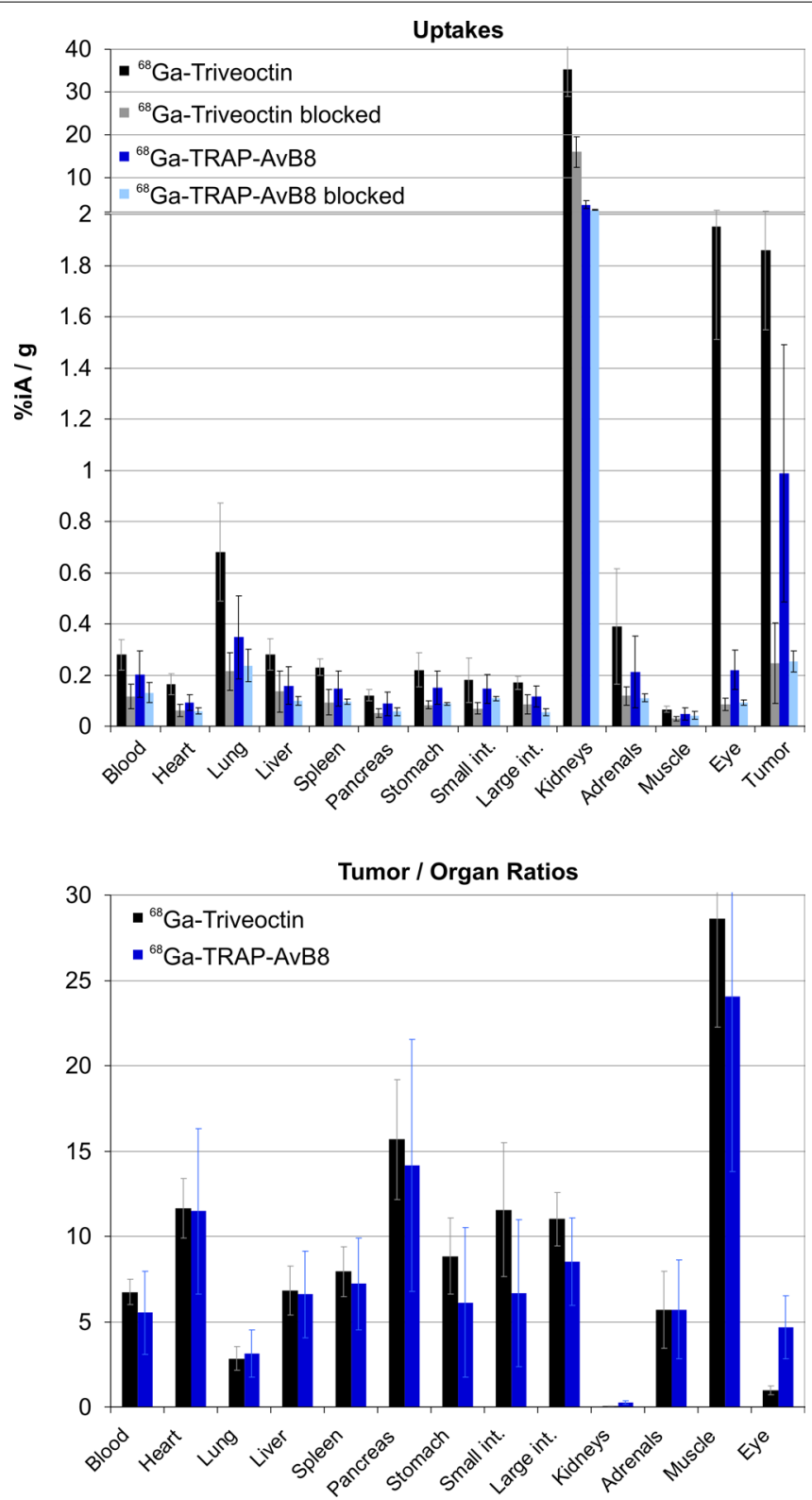

Fig. 3 Biodistribution of ${ }^{68} \mathrm{Ga}$-Triveoctin, 60 min p.i. $(43 \pm 13$ pmol, $n=6$; blockade with $60 \mathrm{nmol}$ Triveoctin injected 5 min prior to the radiopharmaceutical, $n=4)$ in MeWo-xenografted SCID mice, uptakes expressed as \% injected dose per gram tissue; mean \pm SD. Data for ${ }^{68} \mathrm{Ga}-T R A P-A v B 8$ (control: $77 \pm 24 \mathrm{pmol}, n=11$; blockade: $n=3$ ) were taken from the literature [18] and are shown for comparison. Data in numerical form are given in the Additional file 1:Table $\mathrm{S} 1$

is apparently neither accumulated in the vitreus nor the lens or the cornea but concentrates in the area of the dorsal layers (Fig. 4). Since astrocyte-expressed $\alpha v \beta 8$ integrin plays an essential role for the vascularization of the developing mouse retina [31], a persistent expression in the mature retina might be responsible for the observed uptake in the eyeballs.

In addition, $\beta 8$ immunohistochemistry (IHC) validation of target expression confirms that there is a non-negligible $\alpha v \beta 8$ expression density on epithelial cells of the lung (Fig. 5b), which apparently can be detected in the PET by the trimer ${ }^{68} \mathrm{Ga}$-Triveoctin but not with the monomer because of its lower affinity.

Figure 5a furthermore shows that $\alpha v \beta 8$-integrin density in a MeWo xenograft can be quite heterogeneous, while it is not entirely clear which factors are determining the observed local differences. Irrespective of that, the given example shows that the higher sensitivity of 


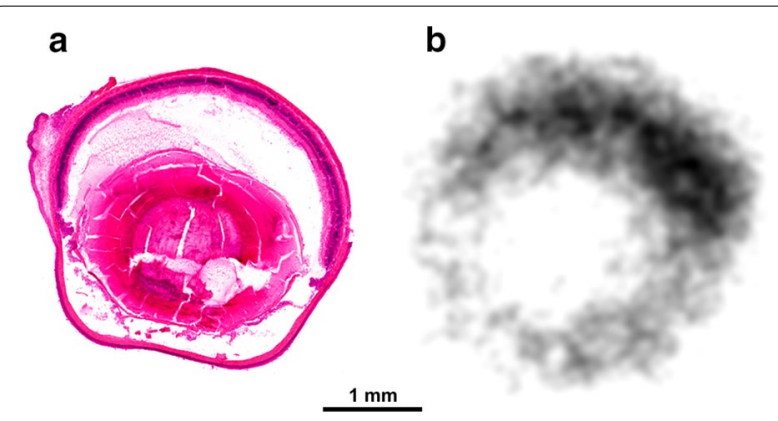

Fig. 4 HE staining (a) and corresponding autoradiography image (b) of a representative sagittal mouse eye cryoslice $(50 \mu \mathrm{m}), 50 \mathrm{~min}$ after administration of ${ }^{68} \mathrm{Ga}$-Triveoctin

${ }^{68} \mathrm{Ga}$-Triveoctin enables imaging $\alpha \mathrm{v} \beta 8$-integrin in tumor regions with low expression, which ${ }^{68} \mathrm{Ga}$-TRAP-AvB8 is not capable of. Figure 6 shows the PET images of the same animal used for IHC (Fig. 5), while the orientation of the slice analyzed by IHC corresponds to the PET position. Obviously, ${ }^{68} \mathrm{Ga}-\mathrm{TRAP}-\mathrm{AvB} 8$ allows only for delineation of the central part of the tumor with high $\beta 8$ expression (Fig. 6a), whereas ${ }^{68} \mathrm{Ga}$-Triveoctin PET readily reproduces the entire, pear-shaped tumor mass (Fig. 6b). Both tracers are, as expected, not significantly accumulated in $\beta 8$-negative tissues, such as liver (Fig. 5c).

The $\mu \mathrm{PET}$ furthermore visualizes that compared to the kidney uptake of ${ }^{68} \mathrm{Ga}$-TRAP-AvB8 (averagely $3.6 \% \mathrm{IA} / \mathrm{g}$, see Additional file 1: Table S1), a substantially higher value is observed for ${ }^{68} \mathrm{Ga}$-Triveoctin $(35 \% \mathrm{IA} / \mathrm{g})$, which is not reduced completely upon blockade but only diminished by slightly more than half (16\%IA/g remaining). A substantial fraction of the remaining uptake could be caused by the larger molecular size, i.e., to less advanced renal clearance observed at the same time point (60 min p.i.) because of slower excretion kinetics. The main
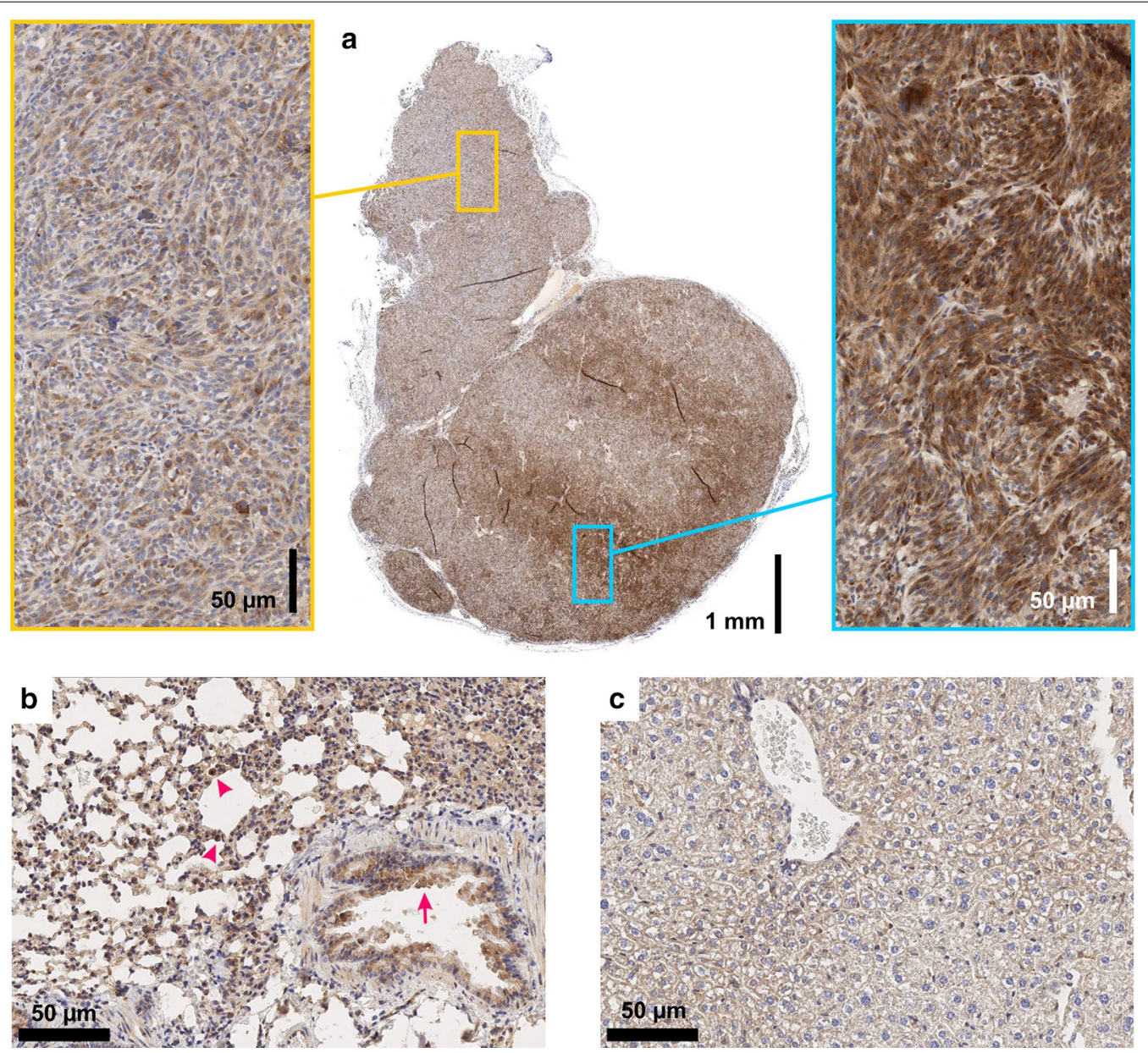

Fig. 5 B8 integrin immunohistochemistry $(\mathrm{IHC})$ of MeWo tumor $(\mathbf{a})$, lung (b), and liver tissue (c) of the same animal used for comparative PET scans (Fig. 6). Magnifications in yellow and cyan frames show MeWo areas with low and high cellular $\beta 8$ integrin expression, respectively. A slight $\beta 8$ expression is observed in the bronchiolar epithelium of lung (arrows) and alveolar macrophages (arrowheads). No $\beta 8$ expression in liver tissue. Note that $\beta 8$ integrin dimerizes only with the ubiquitous av monomer, which is why $\beta 8$ is limiting and indicative for actual av $\beta 8$ distribution 


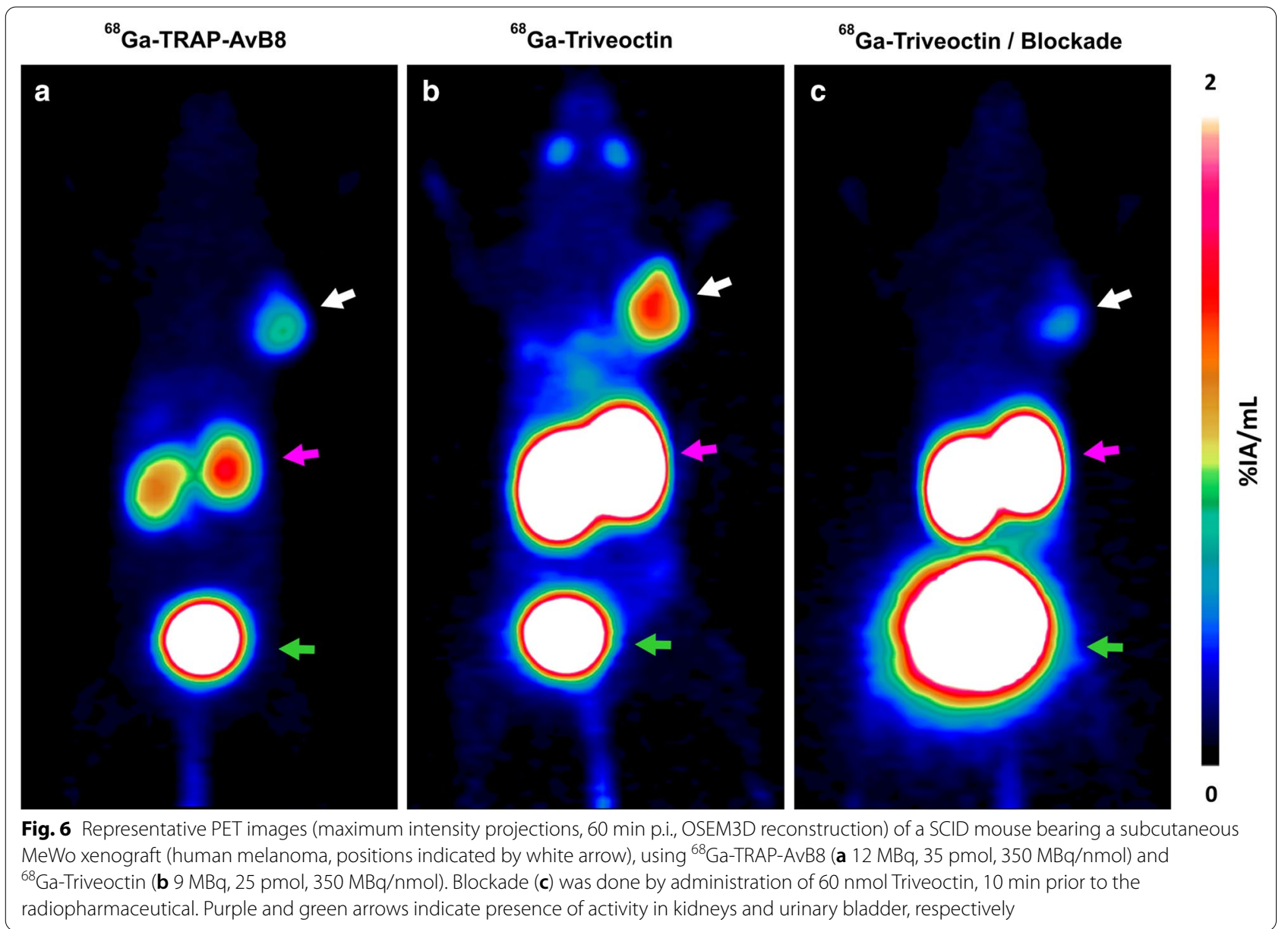

reason for the elevated kidney uptake might however be the expression of $\alpha v \beta 8$-integrin on mural mesangial cells $[32,33]$. The markedly higher uptake of ${ }^{68} \mathrm{Ga}$-Triveoctin can therefore be interpreted as another sign of its target sensitivity, i.e., its superior capability of visualizing mesangial $\alpha v \beta 8$-integrin expression in mice.

\section{${ }^{68} \mathrm{Ga}$-Triveoctin PET in human}

While ${ }^{68} \mathrm{Ga}$-Triveoctin showed only a low soft tissue uptake in a human subject, notable tracer accumulations with descending intensity were observed in kidneys, urinary bladder, choroid plexus, infraadrenal (likely a ganglia), spleen, gastric mucosa, retina, liver, larger vessels, salivary glands and intestine (Fig. 7). As expected, renal uptake decreased over time. The tracer accumulation in the choroid plexus, the coelic ganglia, the spleen, the gastric mucosa, the retina, and the liver showed no relevant change during the imaging period, while there was a slight increase in the intestinal uptake and a decrease in the retained vascular activity (Table 2).

Based on the data shown in Table 2 which implicates renal excretion with a biological half life of $1.8 \mathrm{~h}$, and an assumed urinary bladder residence of $0.3 \mathrm{~h}$, dosimetry calculations using OLINDA yielded a moderate effective dose (ICRP 60) of 3.00E-02 mSv/MBq. Assuming that an activity of $100 \mathrm{MBq}{ }^{68} \mathrm{Ga}$-Triveoctin is sufficient for a PET scan at 30-60 min p.i., up to 6 investigations could be performed without exceeding the $20 \mathrm{mSv}$ limit.

\section{Discussion}

Radiotracer design: why a trimer?

Several studies have shown quite consistently that combining more than a single copy of a given targeting molecule (frequently referred to as multimerization) reliably increases the overall avidity of such constructs (for examples featuring RGD peptides, see refs [26, 34-39]), and ligand multiplicity is normally correlated to target uptake [40] (we are only aware of a single counterexample reported) [38]. However, multimerization does not necessarily improve the image quality or the overall diagnostic value, most likely because the larger molecular size and a different polarity profile (as compared to the respective monomers) frequently spoils the fundamental 


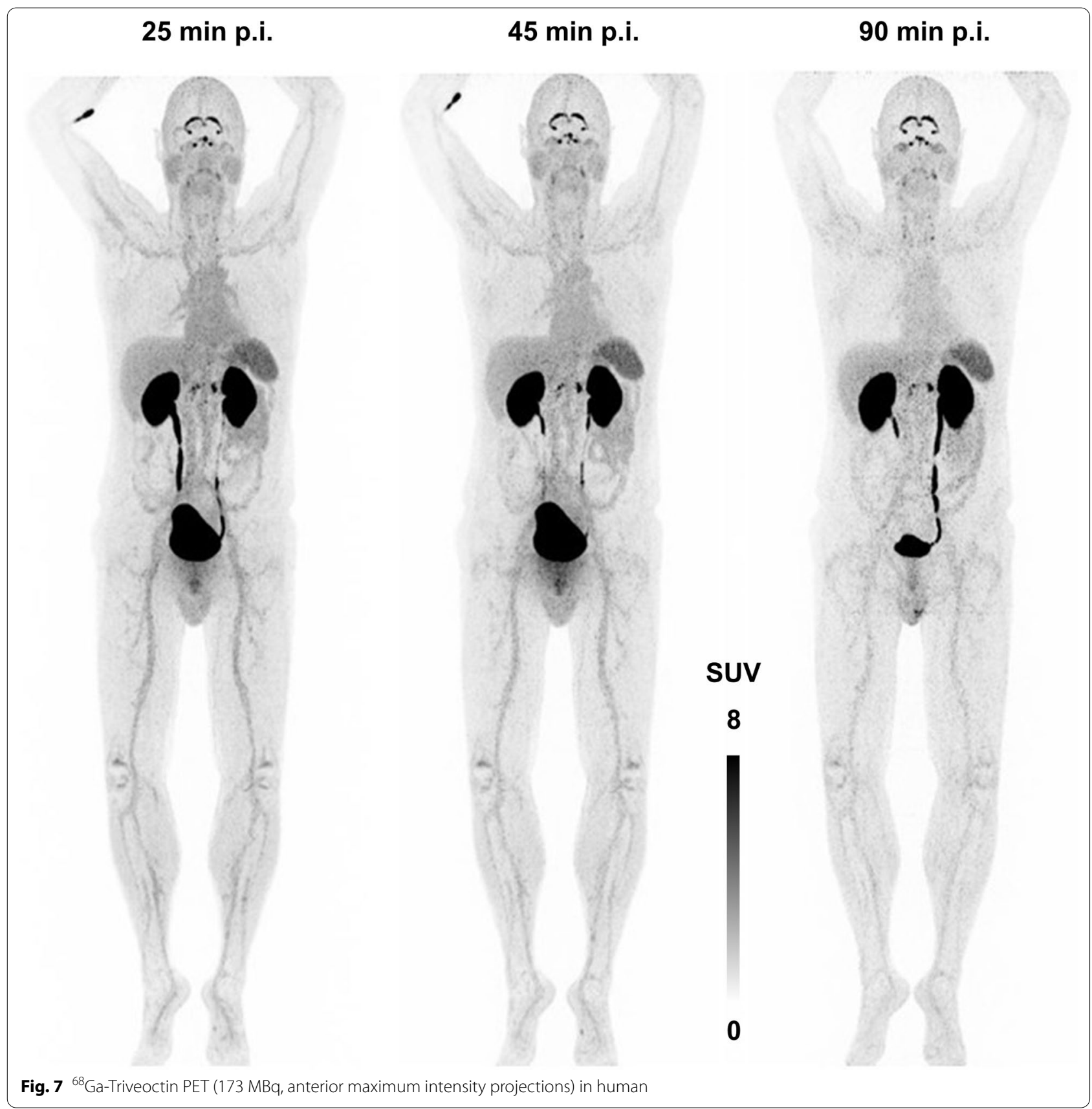

pharmacokinetic properties, for instance, increases unspecific organ uptake and -retention, or alters the excretion route and -velocity [40]. It is furthermore obvious that the hydrophilicity-enhancing effect of certain highly polar radiometal chelates, which can improve the overall pharmacokinetics of their conjugates with non-polar peptides [41], is less pronounced for multimers comprising a single chelate and several peptide moieties. Multimers of comparably nonpolar peptides thus may show unsuitable pharmacokinetics because of overall insufficient hydrophilicity [26]. The polarity of c(GLRGDLp(NMe)K) itself must therefore be regarded as the main reason why ${ }^{68} \mathrm{Ga}$-Triveoctin possesses a suitable hydrophilicity $\left(\log D_{\mathrm{OW}}=-3.1\right)$, and its higher av $\beta 8$-integrin affinity and subtype selectivity can actually translate into favorable imaging characteristics. The ${ }^{68}$ Ga chelator TRAP [21] was chosen as a scaffold not only because its structure allows for facile elaboration of 
Table 2 Standard uptake values (SUV mean SUV $_{\max }$ in parentheses) for selected areas of a PET scan in human (Fig. 7)

\begin{tabular}{|c|c|c|c|c|c|c|}
\hline \multirow{2}{*}{$\begin{array}{l}\text { Organ } \\
\text { Blood (thoracic aorta) }\end{array}$} & \multicolumn{2}{|c|}{$25 \min$ p.i } & \multicolumn{2}{|c|}{$45 \min p . i$} & \multicolumn{2}{|c|}{$90 \min p . i$} \\
\hline & 2.43 & $(3.49)$ & 1.85 & $(3.22)$ & 1.61 & (3.02) \\
\hline Heart & 2.27 & $(4.11)$ & 1.88 & (3.43) & 1.48 & $(2.81)$ \\
\hline Lung (avg.) & 0.72 & $(1.09)$ & 0.64 & $(1.24)$ & 0.50 & $(1.03)$ \\
\hline Liver & 2.25 & $(4.26)$ & 1.75 & (3.19) & 1.94 & $(3.74)$ \\
\hline Spleen & 3.97 & $(5.78)$ & 3.97 & $(5.79)$ & 3.81 & $(5.64)$ \\
\hline Pancreas & 1.75 & (3.19) & 1.64 & $(3.21)$ & 1.30 & $(2.35)$ \\
\hline Stomach & 2.84 & $(5.01)$ & 2.62 & $(4.99)$ & 2.22 & $(4.08)$ \\
\hline Small intestine & 2.20 & $(4.06)$ & 2.05 & (3.91) & 2.07 & $(4.18)$ \\
\hline Large intestine (ascending) & 1.50 & $(3.07)$ & 1.24 & $(2.48)$ & 1.16 & $(2.11)$ \\
\hline Kidneys (avg.) & 43.7 & $(78.2)$ & 23.4 & $(52.8)$ & 24.5 & $(54.9)$ \\
\hline Urinary bladder & 93.2 & $(129)$ & 126 & (206) & 116 & $(172)$ \\
\hline Adrenals (avg.) & 2.27 & $(4.12)$ & 2.15 & (3.70) & 2.10 & $(3.76)$ \\
\hline Muscle & 0.78 & $(1.45)$ & 0.71 & $(1.40)$ & 0.82 & $(1.60)$ \\
\hline Eye (avg.) & 2.11 & $(3.82)$ & 2.34 & $(4.35)$ & 2.64 & $(4.78)$ \\
\hline Coeliac plexus (avg.) & 6.51 & $(12.3)$ & 6.80 & $(12.2)$ & 6.07 & (11.3) \\
\hline Choroid plexus & 13.7 & $(26.9)$ & 11.1 & $(20.8)$ & 9.71 & $(17.4)$ \\
\hline
\end{tabular}

trimers [25, 30], but also because it tolerates comparably high concentrations of frequently occurring metal ion contaminants in generator eluates and ${ }^{68} \mathrm{Ga}$ labeling solutions, such as $\mathrm{Fe}^{\mathrm{III}}$ [42], $\mathrm{Zn}^{\mathrm{II}}$, and $\mathrm{Cu}^{\mathrm{II}}$ [43], and therefore enables highly efficient and robust radiolabeling procedures [44].

\section{Preclinical versus human av $\beta 8$-integrin PET}

Comparison of human PET data with murine ex-vivo distribution reveals several discrepancies, most strikingly, regarding eye uptake, which is high in mice but insignificant in human. Whether this is related to species or subject age (in relation to their typical life spans) cannot be answered on the basis of the existing data, but eye uptake seems to be an artifact of the preclinical experiments. Likewise, the kidney-to-blood and -to-muscle ratios at 90 min p.i. in human (approx. 15 and 30, respectively) are about 8 and 16 times, respectively, lower than in mice (126 and 505, respectively). The relatively high kidney uptake in mice thus also appears to be a mouse artifact, which might in part be related to the expression of $\alpha v \beta 8$ integrin on mural mesangial cells [32, 33], but also to different excretion kinetics of the fairly large molecule. On the other hand, a known $\beta 8$-integrin expression in normal human lung epithelial cells [11] is reflected by the mouse model (Fig. 4b). Although this leads to elevated tracer uptake per tissue weight in the mouse lung, no corresponding per-volume signal is observed in human PET because of the high spatial dilution of the nuclide owing to the high porosity of intact lung tissue.

\begin{tabular}{|c|c|}
\hline Organ & Dose (mGy/MBq) \\
\hline Adrenals & $2.69 \mathrm{E}-02$ \\
\hline Brain & $5.23 \mathrm{E}-03$ \\
\hline Breasts & $5.46 \mathrm{E}-03$ \\
\hline Gallbladder wall & $1.00 \mathrm{E}-02$ \\
\hline LLI wall & $2.08 \mathrm{E}-02$ \\
\hline Small intestine & $3.52 \mathrm{E}-02$ \\
\hline Stomach wall & $1.95 \mathrm{E}-02$ \\
\hline ULI wall & $1.57 \mathrm{E}-02$ \\
\hline Heart wall & $1.52 \mathrm{E}-02$ \\
\hline Kidneys & $2.60 \mathrm{E}-01$ \\
\hline Liver & $2.43 \mathrm{E}-02$ \\
\hline Lungs & $7.83 \mathrm{E}-03$ \\
\hline Muscle & $7.23 \mathrm{E}-03$ \\
\hline Ovaries & $1.13 \mathrm{E}-02$ \\
\hline Pancreas & $2.01 \mathrm{E}-02$ \\
\hline Red marrow & $6.48 \mathrm{E}-03$ \\
\hline Osteogenic cells & $8.89 \mathrm{E}-03$ \\
\hline Skin & $5.60 \mathrm{E}-03$ \\
\hline Spleen & $4.42 \mathrm{E}-02$ \\
\hline Testes & $8.14 \mathrm{E}-03$ \\
\hline Thymus & $6.17 \mathrm{E}-03$ \\
\hline Thyroid & $5.72 \mathrm{E}-03$ \\
\hline Urinary bladder wall & $3.42 \mathrm{E}-01$ \\
\hline Uterus & $1.57 \mathrm{E}-02$ \\
\hline Total body & $9.41 \mathrm{E}-03$ \\
\hline
\end{tabular}




\section{Implications and clinical perspective of av $\beta 8$-integrin imaging}

The existing insights into the expression and functions of $\alpha v \beta 8$-integrin, which were gained mainly from cell studies and histological data, do not allow for a valid conclusion whether or not this receptor might be suited for a "if you can see it, you can treat it" radionuclide imaging and -therapy approach similar to the highly popular and successful sst2- and PSMA-targeted theranostics [45]. While there is yet no systematic, large-cohort-based data on $\alpha v \beta 8$ expression for a comprehensive range of tumor types or conditions, a recent histological study indicated a high proportion of $\beta 8$-positive tumor cells in various carcinomas (ovarian, uterine endometrioid, skin, in situ breast ductal, gastric adenocarcinoma, and particularly oral squamous cell carcinoma), although based on only relatively small numbers of patient specimen (3-22 per entity) [46]. Theranostic applications targeting $\alpha v \beta 8$ integrin therefore do not seem to be unrealistic but remain to be thoroughly investigated.

Beyond the classic theranostic paradigm, the involvement of $\alpha v \beta 8$ in major oncogenic pathways, such as TGF$\beta 1$ signaling and EMT, might ultimately render $\alpha v \beta 8-P E T$ useful for clinical reasoning and personalized medicine, such as for cancer prognosis and stratification of patients for certain chemotherapies. In view of a high relevance of PET imaging of the TGF- $\beta$ signaling pathway adressing downstream targets [47], $\alpha v \beta 8$-PET might augment and/ or substitute such approaches. According to the current state of knowledge, it appears furthermore plausible that tumors with an elevated $\alpha v \beta 8$ level could be resistant to TGF- $\beta$-mediated growth suppression (otherwise, they would inhibit their own progression and thus could not have developed in the first place). Such tumors, for which TGF- $\beta$ acts as a growth promoter [10], should be susceptible to treatment with TGF- $\beta$ inhibitors. $\alpha v \beta 8$-Integrin PET might therefore be useful for selecting appropriate patients for anti-TGF- $\beta$ therapies $[14,48]$. Nishimura and colleagues recently went even further and proposed that rather than targeting latent or free TGF- $\beta$ itself, inhibition of ligands and receptors involved in TGF- $\beta$ activation, and particularly of $\alpha v \beta 8$-integrin, might allow for a TGF- $\beta$-directed therapy with an improved cell type and context specificity [46]. This approach could potentially help to mitigate the systemic toxicity arising from a global loss of the essential homeostatic functions of TGF- $\beta$ upon blockade $[49,50]$. Likewise, $\alpha v \beta 8$-integrin itself has been suggested as a drug target, e.g., for treatment of GBM [15] as well as to overcome a gefitinib resistance of hepatic cancer [51] or radiochemoresistance of pancreatic ductal adenocarcinoma [52]. In case of a future application of anti- $\alpha v \beta 8$-agents for such purposes, patient selection based on $\alpha v \beta 8$-specific noninvasive imaging obviously makes sense. In this respect, the comparably low overall dose allowing for repeated ${ }^{68} \mathrm{Ga}$-Triveoctin PET (up to 6 scans below the $20 \mathrm{mSv}$ limit) might even allow for in-depth studies of target expression as a response to therapy.

\section{Conclusion}

The $\alpha v \beta 8$-integrin PET diagnostic ${ }^{68} \mathrm{Ga}$-Triveoctin was obtained by trimerization of the cyclic peptide cyclo(GLRGDLp(NMe)K) on the TRAP chelator scaffold. Because of its high $\alpha v \beta 8$-integrin affinity, the tracer enabled sensitive in-vivo imaging in murine tumor xenografts. PET in human confirmed a favorable biodistribution with low background, underscoring the potential of ${ }^{68} \mathrm{Ga}$-Triveoctin for future clinical investigation of $\alpha v \beta 8$-integrin expression, e.g., for conditions associated with TGF- $\beta$ dysregulation.

\section{Supplementary information}

Supplementary information accompanies this paper at https://doi. org/10.1186/s13550-020-00706-1.

Additional file 1: Synthesis and analytical data for Triveoctin, radio-TLC for ${ }^{68} \mathrm{Ga}$-Triveoctin, and small-animal biodistribution data for ${ }^{68} \mathrm{Ga}$-Triveoctin in numerical form (table).

\section{Acknowledgements}

The authors thank Sybille Reder, Markus Mittelhäuser and Hannes Rolbieski for assistance with animal PET, Olga Seelbach and Marion Mielke for histological and immunohistochemical workup, Gerd Wunderlich for the radiosynthesis for in-human application, and Liane Oehme for the dosimetry calculations.

\section{Authors' contributions}

Conceived and designed the experiment: NGQ, JN, FR, JK. Performed the experiments: NGQ, KS, FR, JK, JN. Analyzed the data: NGQ, JN, KS, WW, SH, JK. Wrote the original manuscript: NGQ, SH, JK, JN. Edited and revised the manuscript: WW, KS. All authors approved the final version of the manuscript.

\section{Funding}

Open Access funding enabled and organized by Projekt DEAL. This study was funded by the Deutsche Forschungsgemeinschaft (SFB 824, Projects A10 and Z2).

\section{Availability of data and materials}

The datasets used and/or analyzed during the current study are available from the corresponding author on reasonable request.

\section{Competing interests}

The authors declare that they have no competing interests.

\section{Ethics approval and consent to participate}

Procedures involving laboratory mice and their care were conducted in conformity with institutional guidelines and with approval from the responsible local authorities (Regierung von Oberbayern, ROB-55.2-2532.Vet_2-18-109). The authors affirm that the patient provided written informed consent prior to the investigation.

\section{Consent for publication}

The authors affirm that the patient provided written informed consent for publication of the images and data in Fig. 7 and Tables 2 and 3, respectively. 


\section{Author details}

${ }^{1}$ Institut für Pathologie Und Pathologische Anatomie, Technische Universität München, Trogerstraße 18, 81675 Munich, Germany. ${ }^{2}$ Klinik Und Poliklinik für Nuklearmedizin, Universitätsklinikum Carl Gustav Carus an der Technischen Universität Dresden, Dresden, Germany.

Received: 16 July 2020 Accepted: 21 September 2020 Published online: 31 October 2020

\section{References}

1. Moyle M, Napier MA, McLean JW. Cloning and expression of a divergent integrin subunit $\beta 8$. J Biol Chem. 1991;266:19650-8.

2. Nishimura SL, Sheppard D, Pytela R. Integrin avß8. J Biol Chem. 1994:269:28708-15.

3. Blobe GC, Schiemann WP, Lodish HF. Role of transforming growth factor $\beta$ in human disease. N Engl J Med. 2000:34:1350-8.

4. Worthington JJ, Klementowicz JE, Travis MA. TGF- $\beta$ : a sleeping giant awoken by integrins. Trends Biochem Sci. 2011;36:47-54.

5. Khan Z, Marshall JF. Thr role of integrins in TGF- $\beta$ activation in the tumour stroma. Cell Tissue Res. 2016;365:657-73.

6. Ha T. Growth factor rattled out of its cage. Nature. 2017;542:40-1.

7. Dong X, Zhao B, lacob RE, Zhu J, Koksal AC, Lu C, Engen JR, Springer TA. Force interacts with macromolecular structure in activation of TGF- $\beta$. Nature. 2017;542:55-9.

8. Mu D, Cambier S, Fjellbirkeland L, Baron JL, Munger JS, Kawakatsu H, Sheppard D, Broaddus VC, Nishimura SL. The integrin av 88 mediates epithelial homeostasis through MT1-MMP-dependent activation of TGF- $\beta$. J Cell Biol. 2002;157:493-507.

9. Brown NF, Marshall JF. Integrin-mediated TGF- $\beta$ activation modulates the tumour microenvironment. Cancers. 2019;11:1221.

10. Inman GJ. Switching TGF- $\beta$ from a tumor suppressor to a tumor promoter. Curr Opin Genet Dev. 2011;21:93-9.

11. Cambier S, Mu DZ, O'Connell D, Boylen K, Travis W, Liu WH, Broaddus VC, Nishimura SL. A role for the integrin av $\beta 8$ in the negative regulation of epithelial cell growth. Cancer Res. 2000;60:7084-93.

12. Adorno M, Cordenonsi M, Montagner M, Dupont S, Wong C, Hann B, Solari A, Bobisse S, Rondina MB, Guzzardo V, et al. A Mutant-p53/Smad complex opposes p63 to empower TGF- $\beta$-induced metastasis. Cell. 2009;137:87-98.

13. Zhang B, Halder SK, Kashikar ND, Cho YJ, Datta A, Gorden DL, Datta PK. Antimetastatic role of Smad4 signaling in colorectal cancer. Gastroenterology. 2010;138:969-80.

14. Villalba M, Evans SR, Vidal-Vanaclocha F, Calvo A. Role of TGF- $\beta$ in metastatic colon cancer: it is finally time for targeted therapy. Cell Tissue Res. 2017:320:29-39

15. Guerrero PA, Tchaicha JH, Chen Z, Morales JE, McCarty N, Wang Q, Sulman EP, Fuller G, Lang FF, Rao G, McCarty JH. Glioblastoma stem cells exploit the av $\beta 8$ integrin-TGF $\beta 1$ signaling axis to drive tumor initiation and progression. Oncogene. 2017:47:6568-80.

16. Mertens-Walker I, Fernandini BC, Maharaj MSN, Rockstroh A, Nelson CC, Herington AC, Stephenson SA. The tumour-promoting receptor tyrosine kinase, EphB4, regulates expression of Integrin- $\beta 8$ in prostate cancer cells. BMC Cancer. 2015;15:164

17. Cambier S, Gline S, Mu D, Collins R, Araya J, Dolganov G, Einheber S, Boudreau N, Nishimura SL. Integrin avß8-mediated activation of transforming growth factor- $\beta$ by perivascular astrocytes. Am J Pathol. 2005;166:1883-94.

18. Reyes SB, Narayanan AS, Lee HS, Tchaicha JH, Aldape KD, Lang FF, Tolias KF, McCarty JH. avß8 integrin interacts with RhoGDI1 to regulate Rac1 and Cdc42 activation and drive glioblastoma cell invasion. Mol Biol Cell. 2013;24:474-82

19. Reichart F, Maltsev OV, Kapp TG, Räder AFB, Weinmüller M, Marelli UK, Notni J, Wurzer A, Beck R, Wester HJ, Steiger K, Di Maro S, Di Leva FS, Marinelli L, Nieberler M, Reuning U, Schwaiger M, Kessler H. Selective targeting of integrin av $\beta 8$ by a highly active cyclic peptide. J Med Chem. 2019;62:2024-37.
20. Kapp TG, Rechenmacher F, Neubauer S, Maltsev O, Cavalcanti-Adam AE, Zarka R, Reuning U, Notni J, Wester HJ, Mas-Moruno C, Spatz J, Geiger $\mathrm{B}$, Kessler $\mathrm{H}$. A comprehensive evaluation of the activity and selectivity profile of ligands for RGD-binding integrins. Sci Rep. 2017;7:39805.

21. Notni J, Šimeček J, Hermann P, Wester HJ. TRAP, a powerful and versatile framework for gallium-68 radiopharmaceuticals. Chemistry. 2011:17:14718-22.

22. Färber SF, Wurzer A, Reichart F, Beck R, Kessler H, Wester HJ, Notni J. Therapeutic radiopharmaceuticals targeting integrin av $\beta 6$. ACS Omega. 2018;3:2428-36.

23. Pohle K, Notni J, Bussemer J, Kessler H, Schwaiger M, Beer AJ. ${ }^{68} \mathrm{Ga}$ NODAGA-RGD is a suitable substitute for ${ }^{18} \mathrm{~F}$-Galacto-RGD and can be produced with high specific activity in a CGMP/GRP compliant automated process. Nucl Med Biol. 2012:39:777-84.

24. Stabin MG, Sparks RB, Crowe E. OLINDA/EXM: the second-generation personal computer software for internal dose assessment in nuclear medicine. J Nucl Med. 2005;46:1023-7.

25. Baranyai Z, Reich D, Vágner A, et al. A shortcut to high-affinity Ga-68 and Cu-64 radiopharmaceuticals: one-pot click chemistry trimerisation on the TRAP platform. Dalton Trans. 2015:44:11137-46.

26. Notni J, Reich D, Maltsev OV, Kapp TG, Steiger K, Hoffmann F, Esposito I, Weichert W, Kessler H, Wester HJ. In vivo PET imaging of the cancer integrin av 36 using ${ }^{68} \mathrm{Ga}$-labeled cyclic RGD nonapeptides. J Nucl Med. 2017;58:671-7

27. Wurzer A, Pollmann J, Schmidt A, Reich D, Wester HJ, Notni J. Molar activity of Ga-68 labeled PSMA inhibitor conjugates determines PET imaging results. Mol Pharmaceutics. 2018:15:4296-302.

28. Notni J, Šimeček J, Wester HJ. Phosphinic acid functionalized polyazacycloalkane chelators for radiodiagnostics and radiotherapeutics: unique characteristics and applications. ChemMedChem. 2014;9:1107-15.

29. Notni J, Hermann P, Havlíčková J, et al. A triazacyclononane-based bifunctional phosphinate ligand for the preparation of multimeric $68 \mathrm{Ga}$ tracers for positron emission tomography. Chem Eur J. 2010;16:7174-85.

30. Notni J, Wester HJ. A practical guide on the synthesis of metal chelates for molecular imaging and therapy by means of click chemistry. Chem Eur J. 2016:22:11500-8.

31. Hirota S, Liu Q, Lee HS, Hossain MG, Lacy-Hulbert A, McCarty JH. The astrocyte-expressed integrin av $\beta 8$ governs blood vessel sprouting in the developing retina. Development. 2011;138:5157-66.

32. Khan S, Lakhe-Reddy S, McCarty JH, Sorenson CM, Sheibani N, Reichardt $L F$, Kim JH, Wang B, Sedor JR, Schelling JR. Mesangial cell integrin av $\beta 8$ provides glomerular endothelial cell cytoprotection by sequestering TGF- $\beta$ and regulating PECAM-1. Am J Pathol. 2011;178:609-20.

33. Lakhe-Reddy S, Li V, Arnold TD, Khan S, Schelling JR. Mesangial cell avß8 -integrin regulates glomerular capillary integrity and repair. Am J Physiol Renal Physiol. 2014;306:F1400-9.

34. Šimeček J, Hermann P, Havlíčková J, et al. A cyclen-based tetraphosphinate chelator for preparation of radiolabeled tetrameric bioconjugates. Chemistry. 2013;19:7748-57.

35. Thumshirn G, Hersel U, Goodman SL, Kessler H. Multimeric cyclic RGD peptides as potential tools for tumor targeting: solid-phase peptide synthesis and chemoselective oxime ligation. Chemistry. 2003;9:2717-25

36. Dijkgraaf I, Kruijtzer JAW, Liu S, et al. Improved targeting of the avß3 integrin by multimerisation of RGD peptides. Eur J Nucl Med Mol Imaging. 2007:34:267-73.

37. Wängler C, Maschauer S, Prante $O$, et al. Multimerization of CRGD peptides by click chemistry: synthetic strategies, chemical limitations, and influence on biological properties. ChemBioChem. 2010;11:1-15.

38. Kaeopookum P, Petrik M, Summer D, Klinger M, Zhai C, Rangger C, Haubner $\mathrm{R}$, Haas $\mathrm{H}$, Hajduch M, Decristoforo C. Comparison of ${ }^{68} \mathrm{Ga}$-labeled RGD mono- and multimers based on a clickable siderophore-based scaffold. Nucl Med Biol. 2019;78-79:1-10.

39. Quigley NG, Tomassi S, Di Leva FS, Di Maro S, Richter F, Steiger K, Kossatz S, Marinelli L, Notni J. Click-chemistry (CuAAC) trimerization of an av $\beta 6$ integrin targeting Ga-68-peptide: enhanced contrast for in-vivo PET imaging of human lung adenocarcinoma xenografts. ChemBioChem. 2020. https://doi.org/10.1002/cbic.202000200.

40. Maschauer S, Einsiedel J, Reich D, Hübner H, Gmeiner P, Wester HJ, Prante $\mathrm{O}$, Notni J. Theranostic value of multimers: lessons learned from trimerization of neurotensin receptor ligands and other targeting vectors. Pharmaceuticals. 2017:10:29. 
41. Šimeček J, Notni J, Kapp TG, Kessler H, Wester HJ. Benefits of NOPO as chelator in gallium-68 peptides, exemplified by preclinical characterization of ${ }^{68} \mathrm{Ga}-\mathrm{NOPO}-\mathrm{c}(\mathrm{RGDFK})$. Mol Pharm. 2014;11:1687-95.

42. Vágner A, Forgács A, Brücher E, Tóth I, Maiocchi A, Wurzer A, Wester HJ, Notni J, Baranyai Z. Equilibrium thermodynamics, formation, and dissociation kinetics of trivalent iron and gallium complexes of triazacyclononane-triphosphinate (TRAP) chelators: unraveling the foundations of highly selective Ga-68 labeling. Front Chem. 2018;6:170.

43. Šimeček J, Hermann P, Wester HJ, Notni J. How is ${ }^{68} \mathrm{Ga}$-labeling of macrocyclic chelators influenced by metal ion contaminants in ${ }^{68} \mathrm{Ge} /{ }^{68} \mathrm{Ga}$ generator eluates? ChemMedChem. 2013;8:95-103.

44. Notni J, Pohle K, Wester HJ. Comparative gallium-68 labeling of TRAP-, NOTA-, and DOTA-peptides: practical consequences for the future of gallium-68-PET. EJNMMI Res. 2012;2:28.

45. Notni J, Wester HJ. Re-thinking the role of radiometal isotopes: Towards a future concept for theranostic radiopharmaceuticals. J Label Compd Radiopharm. 2018;61:141-53.

46. Takasaka N, Seed RI, Cormier A, Bondesson AJ, Lou J, Elattma A, Ito S, Yanagisawa H, Hashimoto M, Ma R, Levine MD, Publicover J, Potts R, Jespersen JM, Campbell MG, Conrad F, Marks JD, Cheng Y, Baron $J L$, Nishimura SL. Integrin av $\beta 8$-expressing tumor cells evade host immunity by regulating TGF- $\beta$ activation in immune cells. JCI Insight. 2018;3:e122591.
47. Rotteveel L, Poot AJ, Bogaard HJ, ten Dijke P, Lammertsma AA, Windhorst AD. In vivo imaging of TGF signalling components using positron emission tomography. Drug Discov Today. 2019;24:2258-72.

48. Korpal M, Kang Y. Targeting the transforming growth factor $\beta$ signalling pathway in metastatic cancer. Eur J Cancer. 2010;46:1232-40.

49. Anderton MJ, Mellor HR, Bell A, Sadler C, Pass M, Powell S, Steele SJ, Roberts RR, Heier A. Induction of heart valve lesions by small-molecule ALK5 inhibitors. Toxicol Pathol. 2011;39:916-24.

50. Vitsky A, Waire J, Pawliuk R, Bond A, Matthews D, Lacasse E, Hawes ML, Nelson C, Richards S, Piepenhagen PA, Garman RD, Andrews L, Thurberg BL, Lonning S, Ledbetter S, Ruzek MC. Homeostatic role of transforming growth factor-beta in the oral cavity and esophagus of mice and its expression by mast cells in these tissues. Am J Pathol. 2009;174:2137-49.

51. Wang WW, Wang YB, Wang DQ, Lin Z, Sun RJ. Integrin $\beta-8$ (ITGB8) silencing reverses gefitinib resistance of human hepatic cancer HepG2/G cell line. Int J Clin Exp Med. 2015;8:3063-71.

52. Jin S, Lee WC, Aust D, Pilarsky C, Cordes N. $\beta 8$ integrin mediates pancreatic cancer cell radiochemoresistance. Mol Cancer Res. 2019;17:2126-38.

\section{Publisher's Note}

Springer Nature remains neutral with regard to jurisdictional claims in published maps and institutional affiliations.

\section{Submit your manuscript to a SpringerOpen ${ }^{\circ}$ journal and benefit from:}

- Convenient online submission

- Rigorous peer review

- Open access: articles freely available online

- High visibility within the field

- Retaining the copyright to your article

Submit your next manuscript at $\boldsymbol{\nabla}$ springeropen.com 